\title{
Port Metabolism and Benefits of Green Zones in City-Port Systems
}

\author{
Bruno Barroca $^{1 *}$ and Maria Fabrizia Clemente ${ }^{2}$ \\ ${ }^{1}$ Gustave Eiffel University, Lab'Urba, France \\ ${ }^{2}$ Department of Architecture, University of Naples Federico II, Italy
}

Submission: February 01, 2021; Published: February 10, 2021

*Corresponding author: Bruno Barroca, Gustave Eiffel University, Lab’Urba, Batiment Lavoisier, Boulevard Descartes, 77454 Marnela-Vallée CEDEX 2, France

Abstract

Climate change has produced new challenges for port infrastructures, requiring the planning of long-term mitigation measures and adaptation actions. In order to be able to orient projects, it is necessary to read ports as complex systems and to understand the dependencies and flows between their parts, and the interaction with city and with environment. Among project actions, the inclusion of green areas provides both mitigation and adaptation benefits.

Keywords: Climate change; Port system; Port metabolism; Mitigation; Adaptation

\section{Introduction}

In the world there is a high concentration of urban settlements along the coast. Several cities have developed over the centuries, finding in the sea a vital element both in urban culture and in socio-economic and productive growth. Urban settlements have progressively consumed soils and resources, depriving and degrading space from the natural environment [1,2]. Ports are key elements in regional and sub-regional economies. In 2005, thirteen of the twenty most populated cities in the world were port cities, such as Shanghai which is also one of the world's largest ports in terms of cargo traffic; trends show how this tendency is accelerating over the years due to globalisation and international trade mechanisms [3]. Dense urbanisation and high concentration of assets make coastal areas highly vulnerable in environmental and climate terms, at the same time urban areas are the main contributors to greenhouse gas (GHG) emissions [4]. In this scenario, port cities represent critical hot spots, since at the waste produced by urban metabolism must be added that produced by port metabolism [5].

Over the last few years there has been an increased consciousness of the effects of urban metabolism on the environment [6]. Cities, in fact, transform natural resources, such as raw materials, fuel and water, into the urban built environment, human biomass, and finally waste [7]. The metabolic perspective can support decision-makers in understanding the urban system and support urban planning, with a focus on resources and waste reduction, for sustainable urban development [8]. In this scenario, the concept of ecosystem service, referring to the integration of green areas, can support and make operational the models and theoretical studies on urban metabolism to improve their transferability to urban planning, influencing decision-making processes and design practices [9].

Today, economic infrastructures are called to respond urgently to the challenges imposed by climate change through mitigation and adaptation measures. Port areas have impacts on the natural environment degrading air, water, soil and sediment quality, damaging natural habitat ecosystems and biodiversity, consuming soils and resources, and producing waste, odours and noise [10]. In the climate context, greenhouse gas emissions are a highly critical element accelerating the dynamics of climate change and global warming, contributing to the increase in the intensity and frequency of natural hazards. In the port context, GHG emissions arise from ship discharges during navigation and docking, from the use and maintenance of buildings and open spaces, from equipment for handling and loading cargo, and finally from the use of heavy vehicles and/or railway systems [11]. About $70 \%$ of GHG emissions from the maritime sector occur in coastal areas [12].

Climate change has created new challenges for ports, producing both risks and opportunities for competitive 
advantage. In urban areas, nature-based solutions - defined by the International Union for the Conservation of Nature(IUCN) as actions to protect, sustainably manage and restore natural or anthropic ecosystems - decrease vulnerability and improve climate resilience by mitigating causes and reducing impacts through adaptation actions, also offering as valid solutions for port areas [13]. In terms of environmental management - understood as the functional organisation for environment protection and sustainable development - the European Sea Ports Organisation (ESPO) identifies every year the ten priorities for European port systems. Since 2017, climate change has been included, while air quality has always been a highly critical element accompanied by energy consumption, recently translated into energy efficiency, and problems related to noise and dredging [14].

In port areas climate mitigation aims to reduce and control emissions, the main strategies identified are the absorption of carbon dioxide $\left(\mathrm{CO}_{2}\right)$ through the inclusion of specific natural ecosystems such as mangrove plantations, rather than traditional hard breakwater, the promotion and use of clean and renewable energies, the energy efficiency of processes and systems and finally the promotion of sustainable transport and mobility systems for employees, passengers and cargo traffics $[15,16]$.

\section{Discussion}

Despite the increasing diffusion of international agendas, ordinances and protocols, the short-term objectives of port governance favour the most obvious and immediate socioeconomic aspects. The short duration of governance mandates means that climate aspects are often not so much considered, except in terms of physical impacts on infrastructure, or functional impacts on operations and workforce.

To understand the way to intervene for climate risk management and for the orientation of climate mitigation and adaptation actions in port systems are necessary to analyse infrastructures as complex structures, composed of systems, subsystems and components. City and port systems are in fact composed of multiple subsystems such as the transport or the energy subsystems, which are themselves composed of multiple components. Between the parts there are direct and indirect flows and dependencies. It is this complexity that makes ports highly vulnerable [17,18] (Figure 1).

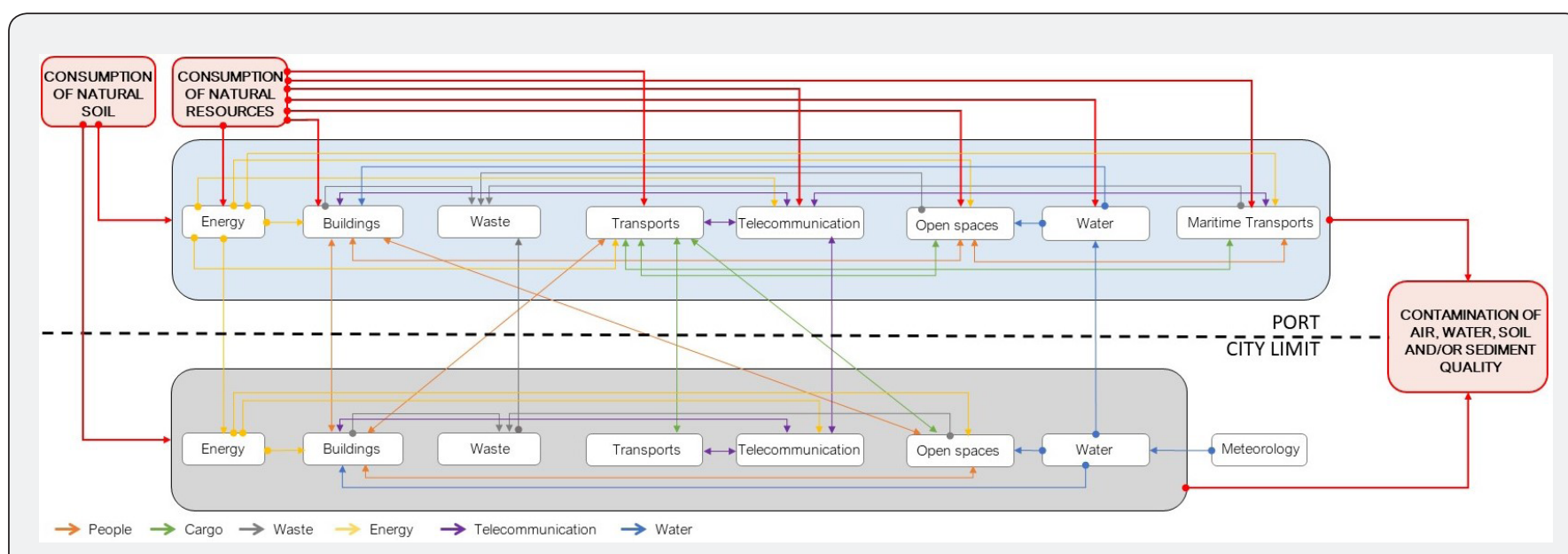

Figure 1: Complex interactions between environment, city and port and systems.

A functional block diagram can support the analysis of operational flows and dependencies within the port infrastructure. This type of analysis also highlights the complex interactions between the environment, the city and the port and the impacts of the port's functionality and existence on the consumption of natural resources and soils, and the degradation of water, air, soil and/or sediment. As highlighted, the city-port interface is dense of interactions, highlighting the need of porosity and permeability to allow the development of activities and the flow of energy, goods and people. At the same time, the port-city limits are highly critical areas also in environmental terms. Recent studies on the port of Alicante show that the highest levels of $\mathrm{PM}_{10}$ derive from the handling operations, mainly of liquid bulk, and from road traffic occurring in the port, the influence on the city area depends on meteorological conditions, in particular on the direction and intensity of the wind. In order to improve air quality, action must be taken in the port area by intervening on the most polluting processes, but also through more extensive measures [19].

Climate mitigation requires medium and long-term planning measures, going beyond the spatial confines of the port territory relating to urban scales, and the temporal limits of port authority mandates, requiring more holistic and long-term strategic objectives. Adaptation actions, which relate to shorter timescales, are at the same time an opportunity to increase competitiveness through improved flows and activities and more efficient management of both natural and human-induced hazards and by improving and optimising the life cycle of physical infrastructures 
[20]. Among climate mitigation actions, the inclusion of green areas allows physical benefits such as absorption of $\mathrm{CO}_{2}$, improvement of thermal comfort and consequently reducing of energy consumption, improving air and water quality. Green zones also contribute to better management of water resources, drought risk and flood risk, by creating highly permeable surfaces [21]. From an economic point of view, the inclusion of green zones can be considered a soft action, as it does not require the use of large financial capital. It also has numerous benefits for the health, comfort and well-being of people who live in the areas, both operators and users [22]. Green areas can be inserted as buffer zones in the port-city limit allowing the coexistence of the two macro-systems or through the insertion of nature-based solutions. The integration of the port's green spaces with the city's green spaces could allow the creation of green network infrastructures.

In Spain, several port authorities have moved to integrate the green in the city-port border and inside the port areas themselves. Among these, the Port Authority of Alicante, as part of the urban integration plan, has created a vegetal barrier with to integrate city and port, and improving the environmental quality and accessibility of spaces [23]. Also, the Barcelona Port Authority, although the port territory is not subject to environmental restrictions, in a joint action with local institutions has launched several programs and actions aimed at climate mitigation and adaptation, especially related to air quality [24]. The monitoring of $\mathrm{PM}_{10}$ through sensors placed in different points of the port area reveals how the values have drastically decreased over the years, complying the permissible limit values since 2013. In the Port Vell area, which is adjacent to the Ciutat Vella, the values have complied with the standards for urban areas since 2008 [25].

\section{Conclusion}

Port areas are critical hot spots in urban systems, especially when ships are docked in ports, since the port metabolism is added to the urban metabolism. Ports are a vulnerable area where investments are being made in both economic and social terms. Climate change imposes new challenges on port infrastructures. The aim is not simply to accompany the energy transition of the maritime transport system but of undertaking more holistic, strategic and long-term governance and sustainable development processes, modifying the liner processes that characterise metabolism, working on the port-city organisation to promote cyclical production and consumption processes. In order to manage these processes, it is necessary to understand the complexity of the infrastructure and move towards medium-longterm climate scenarios. Functional block diagrams can be used to understand the interactions between environment, port and city.

Among climate actions, the incorporation of nature-based solutions should become part of port planning and design, and the benefits would be multiple in both direct and indirect aspects. The naturalisation of the port could also allow access to specific programs, funds and defiscalisation plans on a national and international scale, allowing competitive development.

\section{Funding}

This work was supported by the French National Agency of Research within the project DéPOs (ANR-18-OURA-0003).

\section{References}

1. Small C, Nicholls R (2003) A Global Analysis of Human Settlement in Coastal Zones. Journal of Coastal Research 19(3): 584-599.

2. Nicholls RJ, Wong PP, Burkett V, Codignotto J, Hay J, et al. (2007) Coastal Systems and Low-Lying Areas; University of Wollongong: Wollongong, Australia.

3. Nicholls RJ, Hanson S, Herweijer C, Patmore N, Hallegatte S, et al. (2008) Ranking Port Cities with High Exposure and Vulnerability to Climate Extremes: Exposure Estimates. OECD Environment Directorate, Working Papers.

4. Nicholls R (2002) Analysis of global impacts of sea-level rise: A case study of flooding. Physics and Chemistry of the Earth, Parts A/B/C 27(32-34): 1455-1466.

5. Wolman A (1965) The metabolism of cities. Scientific American 213(3): e179-e190.

6. Zhang Y, Yang Z, Yu X (2015) Urban Metabolism: A Review of Current Knowledge and Directions for Future Study. Environmental Science \& Technology 49(19): 11247-11263.

7. Decker EH, Elliott S, Smith FA, Blake DR, Rowland FS (2000) Energy and material flow through the urban ecosystem. Annual Review of Energy and the Environment 25: 685-740.

8. Barles S (2010) Society, energy and materials: the contribution of urban metabolism studies to sustainable urban development issues. Journal of Environmental Planning and Management 53(4): 439-455.

9. Perrotti D, Stremke S (2020) Can urban metabolism models advance green infrastructure planning? Insights from ecosystem services research. Environment and Planning B Planning and Design 47(4): 678-694.

10. Pash HS, Ebadi T, Pourahmadi A, Parhizkar Y (2017) Analysis of Most Important Indices in Environmental Impacts Assessment of Ports. Civil Engineering Journal 3(10).

11. Konstantzos GE, Saharidis GKD, Loizidou M (2017) Development of a model for assessing Greenhouse Gas (GHG) emissions from terminal and drayage operations. Operational Research 17: 807-819.

12. Chen J, Huang T, Xie X, Lee PTW, Hua C (2019) Constructing governance framework of a green and smartport. Journal of Marine Science and Engineering 7(4): 83.

13. Kabisch N, Frantzeskaki N, Pauleit S, Naumann S, Davis M, et al. (2016) Nature-based solutions to climate change mitigation and adaptation in urban areas: Perspectives on indicators, knowledge gaps, barriers, and opportunities for action. Ecology and Society 21(2): 39.

14. ESPO - European Sea Ports Organisation (2020) Environmental Report 2020.

15. Wilmsmeier G (2020) Climate change adaptation and mitigation in ports: Advances in Colombiain. In: Ng AKY, Monios J, Jiang C (Eds.), Maritime Transport and Regional Sustainability, Elsevier, pp. 133-150.

16. Taneja P, Hoek A, Koningsveld M (2020) A nature-based solution for sustainable port development in Port of Kuala Tanjung, Indonesia. Coastal Engineering Proceedings 51. 
17. Serre D, Barroca B, Balsells M, Becue V (2018) Contributing to Urban Resilience to Floods with Neighbourhood Design: The Case of Am Sandtorkai/Dalmannkai in Hamburg. Journal of Flood Risk Management 11(S1): 69-83.

18. Gonzva M, Barroca B, Gautier PE, Diab Y (2017) Modeling disruptions causing domino effects in urban guided transport systems faced by flood hazards. Natural Hazards 86: 183-201.

19. Clemente María Á, Yubero E, Galindo N, Crespo J, Nicolás J, et al. (2021) Quantification of the impact of port activities on $\mathrm{PM}_{10}$ levels at the port-city boundary of a Mediterranean city. Journal of Environmental Management 281: 111842.

20. Yang Z, Ng AKY, Lee PTW, Wang T, Qu Z, et al. (2018) Risk and cost evaluation of port adaptation measures to climate change impacts. Transportation Research Part D: Transport and Environment 61(Part B): 444-458.
21. Demuzere M, Orru K, Heidrich O, Olazabal E, Geneletti D, et al. (2014) Mitigating and adapting to climate change: Multi-functional and multi-scale assessment of green urban infrastructure. Journal of Environmental Management 146: 107-115.

22. Lee ACK, Maheswaran R (2011) The health benefits of urban green spaces: a review of the evidence. Journal of Public Health 33(2): 212222.

23. Port de Alicante (2019) Reports.

24. Aregall MG, Bergqvist R (2019) Green port initiatives for a more sustainable port-city interaction: The case study of Barcelona. Maritime Transport and Regional Sustainability, pp. 109-132.

25. Port de Barcelona (2020) Atmospheric environment.

\section{Your next submission with Juniper Publishers} will reach you the below assets

- Quality Editorial service

- Swift Peer Review

- Reprints availability

- E-prints Service

- Manuscript Podcast for convenient understanding

- Global attainment for your research

- Manuscript accessibility in different formats

( Pdf, E-pub, Full Text, Audio)

- Unceasing customer service

Track the below URL for one-step submission https://juniperpublishers.com/online-submission.php 